\title{
Penerapan Metode Case Based Reasoning dan K-Nearest Neighbor untuk Diagnosa Penyakit dan Hama pada Tanaman Karet
}

\author{
Heni Sulistiani ${ }^{\# 1}$, Imam Darwanto ${ }^{* 2}$, Imam Ahmad ${ }^{\# 3}$

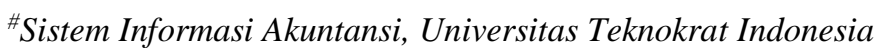 \\ Jl. ZA. Pagar Alam No. 9-11, Labuhan Ratu Bandar Lampung \\ 1henisulistianieteknokrat.ac.id \\ ${ }^{3}$ imamahmad66 6@gmail. com \\ * Universitas Teknokrat Indonesia \\ Jl. ZA. Pagar Alam No. 9-11, Labuhan Ratu Bandar Lampung \\ 2 imamdarwanto76@gmail. com
}

\begin{abstract}
Abstrak- Petani karet di wilayah Kabupaten Tulang Bawang sering menemukan masalah seperti penyakit dan hama tanaman karet yang dapat mengakibatkan kematian pada tanaman karet, antara lain penyakit pada bidang sadap, dan hama penggangu seperti rayap dan kutu tanaman. Penyakit tersebut dapat dideteksi melalui gejalagejala yang ditimbulkan. Akan tetapi untuk mengetahui jenis penyakit yang menyerang tanaman karet diperlukan seorang pakar pertanian dan perkebunan. Namun, saat ini petani di Tulang Bawang masih memliki kekurangan dalam hal pengetahuan untuk pencegehan dan penanganan penyakit tanaman karet. Untuk itu, diperlukan suatu sistem yang berisikan pengetahuan tertentu dalam hal kepakaran melalui pendekatan kemampuan manusia di salah satu bidang. Salah satunya adalah sistem pakar. Berbagai metode telah diterapkan untuk membangun sistem pakar, diantaranya adalah Metode Case Base Reasoning dan $\mathrm{K}$ Nearest Neighbor. Metode ini digunakan untuk mencari solusi dari permasalahan berdasarkan pengalaman kasus masa lalu dan pendekatan untuk mencari kasus dengan menghitung kedekatan antara kasus baru dengan kasus lama. Hasil pengujian keakuratan kesesuaian antara data testing yang diperoleh dari pakar dengan hasil pengolahan sistem adalah sebesar $80 \%$.
\end{abstract}

\section{Kata kunci- CBR, KNN, Karet, Sistem Pakar, Penyakit}

\section{Pendahuluan}

Tanaman karet merupakan salah satu komoditas pertanian penting untuk perkebunan Indonesia dan lingkup internasional. Di Indonesia karet merupakan salah satu penghasil devisa yang besar karena mampu memberikan kontribusi sebagai komoditi ekspor. Pendapatan devisa dari komoditi ini pada tahun 2014 produksi karet alam Indonesia sebesar 2,6 juta ton memberikan kontribusi devisa senilai US\$ 4,7 juta [1]. Namun dalam pengelolaan karet, petani sering menemukan masalah seperti penyakit dan hama pada tanaman karet yang dapat mengakibatkan kematian pada tanaman karet. Berdasarkan wawancara yang dilakukan kepada petani karet yang ada di wilayah Kabupaten Tulang Bawang bahwa sering ditemukan penyakit dan hama berupa penyakit pada akar, penyakit pada bidang sadap, dan hama penggangu seperti rayap dan kutu tanaman.

Adanya penyakit dan hama pada tanaman karet dapat menyebabkan kerusakan dan kerugian dalam hal biaya untuk penanggulangannya. Upaya-upaya pencegahan dan pengamatan secara dini perlu dilakukan secara terus menerus. Namun, petani karet masih memiliki pengetahuan yang kurang untuk proses penanganan penyakit dan hama karet tersebut. Seiring dengan perkembangan teknologi di berbagai bidang menjadikan para pengembang teknologi mampu membuat aplikasi yang lebih memudahkan masyarakat dalam memperoleh informasi [2].

Maka sebab itu, perlu dikembangkan sebuah sistem atau aplikasi yang memiliki kemampuan seperti seorang pakar dalam mendeteksi gejala penyakit dan hama pada tanaman karet. Sistem tersebut dapat berupa sistem pakar. Sistem pakar merupakan sebuah sistem yang mengadopsi pengetahuan manusia ke komputer yang menggabungkan dasar pengetahuan (knowledge based) dengan sistem inferensi untuk menggantikan fungsi seorang pakar dalam menyelesaikan suatu masalah [3]. Sistem pakar juga dapat diartikan sebagai kumpulan fakta-fakta yang telah dikumpulkan guna menunjukkan gejala penyakit tertentu dan dapat memberikan penjelasan berdasarkan konsultasi dengan pakar yang pernah dilakukan [4].

Dalam pengembangan sistem pakar, banyak metode yang sudah digunakan oleh para peneliti. Seperti metode certainty factor yang menyatakan kepercayaan dalam 
sebuah kejadian baik itu fakta atau hipotesis berdasarkan bukti atau penilaian pakar dan metode certainty factor bukanlah probabilitas [5]. Metode lainnya yaitu case based reasoning (CBR) yang bertujuan untuk menyelesaikan suatu kasus baru dengan cara mengadaptasi solusi-solusi yang terdapat pada kasuskasus sebelumnya yang mirip dengan kasus baru tersebut [6]. Dalam CBR terdapat beberapa proses yaitu retrieve, reuse, revise dan retain [7]. Dan masih banyak lagi metode yang dapat digunakan untuk sistem pakar seperti forward chaining [8][9][10], backward chaining [10], dempster shafer [11]. Dengan adanya penerapan metode dalam sistem pakar diharapkan dapat membantu para petani untuk mendeteksi penyakit dan hama pada tanaman karet berdasarkan gejala-gejalanya.

Berdasarkan dari latar belakang yang telah dijelaskan, rumusan masalah dalam penelitian ini yaitu bagaimana mengimplementasikan metode $\mathrm{CBR}$ dan $\mathrm{KNN}$ dalam perangkat lunak berbasis website untuk mendeteksi penyakit dan hama tanaman karet. Sedangkan batasan masalah yaitu sistem diagnosa penyakit dan hama yang dibangun hanya dapat menentukan penyakit dan hama pada tanaman karet. Tujuan penelitian yaitu mengimplementasikan metode CBR dan KNN dalam perangkat lunak berbasis website untuk mendeteksi penyakit dan hama pada tanaman karet dan manfaat dari penelitian ini yaitu memberikan kemudahan bagi petani karet untuk melakukan diagnosa penyakit dan hama pada tanaman karet serta cara penanganannya.

\section{TINJAUAN PUSTAKA}

\section{A. Penelitian Terdahulu}

Penelitian mengenai sistem pakar untuk mendeteksi penyakit tanaman karet pernah dikembangkan sebelumnya oleh para peneliti terdahulu, antara lain mendeteksi penyakit pada tanaman karet dengan menggunakan metode certainty factor [5]. Penelitian ini menekankan pada dua aspek utama yaitu gejala-gejala dan jenis penyakit tanaman karet. Hasil penelitian menunjukkan bahwa penerapan metode certainty factor pada penelitian ini, memiliki akurasi sebesar $100 \%$ dari hasil diagnosa sistem pakar. Penelitian lainnya yaitu menggunakan metode Dempster-Shafer untuk mendeteksi penyakit tanaman karet [12]. Dengan adanya sistem pakar ini dapat membantu atau mempermudah pekerjaan para pakar kerena memindahkan pengetahuan para pakar ke aplikasi yang disertai dengan pengendalian penyakit.

Dalam penelitian ini juga melakukan perbandingan metode Case Based Reasoning dan K-Nearest Neighbor. Yang bertujuan untuk mencari solusi dari permasalahan deteksi penyakit tanaman karet berdasarkan pengalaman kasus masa lalu dan pendekatan untuk mencari kasus.

\section{B. Sistem Pakar}

Sistem pakar adalah sistem berbasis komputer yang menggunakan pengetahuan, fakta, dan teknik penalaran dalam memecahkan masalah yang biasanya hanya dapat dipecahkan oleh seorang pakar dalam bidang tertentu [13].
Terdapat beberapa metode yang dapat diterapkan untuk pengembangan sistem pakar, salah satunya adalah metode case based reasoning. Case Based Reasoning adalah salah satu metode untuk membangun sistem pakar dengan pengambilan keputusan dari kasus yang baru dengan berdasarkan solusi dari kasus-kasus sebelumnya. Konsep dari metode case based reasoning ditemukan dari ide dengan menggunakan pengalaman-pengalaman yang terdokumentasi untuk menyelesaikan masalah yang baru [14]. Secara keseluruhan model CBR Cycle dapat digambarkan dengan proses pada Gambar 1 .

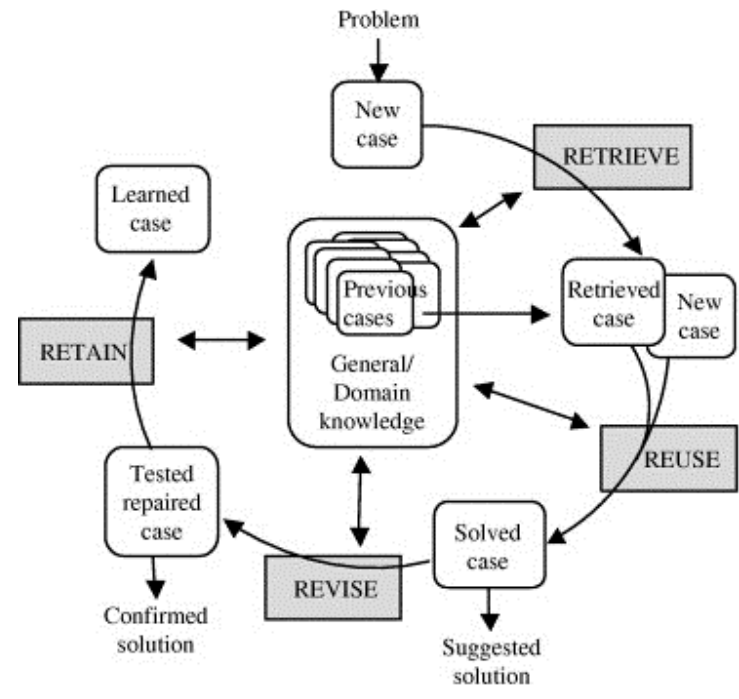

Gambar. 1 CBR cycle

Dari gambar 1 dapat dilihat bahwa dalam CBR cycle terdapat 4 proses yang dilakukan, antara lain Retrieve, Reuse, Revise dan Retain.

Retrieve merupakan proses untuk mendapatkan kembali kasus terdahulu yang serupa dengan kasus yang sedang dihadapi [15]. Reuse merupakan proses untuk menggunakan kembali informasi dan pengetahuan dalam kasus terdahulu untuk menyelesaikan masalah yang dihadapi. Revise merupakan proses memperbaiki solusi yang telah ada sebelumnya. Retain merupakan proses penyimpanan kasus baru dan solusinya untuk digunakan dalam menyelesaikan kasus berikutnya. Keempat proses di atas akan terus dilakukan ketika menghadapi kasus baru.

\section{Algoritma Nearest Neighbor}

Algoritma nearest neighbor adalah pendekatan untuk mencari kasus dengan menghitung kedekatan antara kasus baru dengan kasus lama, yaitu berdasarkan pada pencocokan bobot dari sejumlah fitur-fitur yang ada [16]. Adapun rumus untuk melakukan perhitungan kedekatan antara dua kasus adalah sebagai berikut :

Kesamaan (Similarity) $(T, S)=\frac{\sum_{i=1}^{n} f\left(T i_{s} S i\right) x W i}{W i}$ 
Keterangan : $T$ (kasus baru), $S$ (kasus yang ada dalam penyimpanan), $N$ (jumlah atribut dalam setiap kasus), $I$ (atribut individu antara 1 s.d. $\mathrm{n}$ ), f (fungsi similarity untuk fitur $I$ dalam kasus $T$ dan kasus $S$ ), $w$ (bobot yang diberikan pada atribut ke-i).

\section{Penyakit dan Hama Tanaman Karet}

Penyakit dan Hama tanaman yang dapat di diagnosa dalam sistem pakar ini sebanyak 7 kasus yaitu, penyakit jamur akar putih, penyakit jamur akar merah, penyakit bidang sadap kanker garis, penyakit bidang sadap mouldy rot, penyakit bidang sadap brown blast (kering alur sadap), hama rayap, dan hama kutu [17].

\section{Metodologi}

\section{A. Kerangka Pemikiran}

Kerangka berpikir ini merupakan suatu argumentasi kita dalam merumuskan hipotesis. Dalam merumuskan suatu hipotesis, argumentasi kerangka berpikir menggunakan logika deduktif dengan memakai pengetahuan ilmiah sebagai premis dasarnya. Dapat dilihat pada gambar 2 .

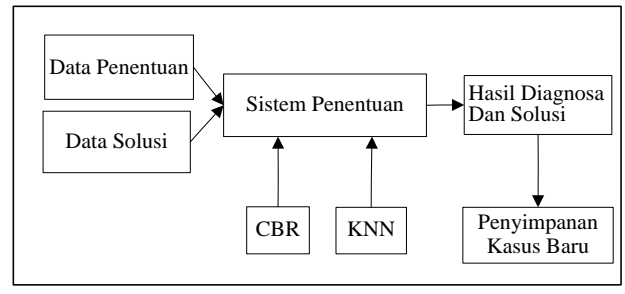

Gambar. 2 Kerangka pemikiran

Data solusi yang di maksud adalah data solusi yang berikan oleh ahli dalam penyakit dan hama pada pohon karet. Sistem penentuan pendekatan merupakan tahapan untuk menentukan penyakit tanaman karet dengan menggunakan metode case based reasoning (CBR) dan metode Algoritma k-nearest neighbor (KNN). Hasil diagnosa berupa hasil penyakit dan hama yang diderita oleh tanaman karet. Penyimpanan kasus baru proses ini dilakukan apabila ada gejala atau penentuan baru yang belum terinputkan atau belum ada pada sistem yang telah berjalan.

Langkah-langkah Penerapan Metode CBR dan KNN dalam Sistem Pakar untuk Diagnosa Penyakit dan Hama Pada Tanaman Karet yang dilakukan dalam penelitian ini antara lain:

1) Communication: Analisis permasalahan sistem merupakan langkah pertama yang dilakukan dalam analisis sistem. Masalah dapat didefinisikan sebagai suatu Gejala yang diinginkan untuk dipecahkan. Hasil pengumpulan data dari seorang pakar, diperoleh data tentang gejala dan bobot yang sering menyerang tanaman karet yang dapat dilihat pada tabel 1 .
TABEL I

DAFTAR GEJALA PENYAKIT DAN HAMA

\begin{tabular}{|c|c|c|}
\hline \multicolumn{3}{|c|}{ Daftar Gejala Penyakit dan Hama Tanaman Karet } \\
\hline No & Gejala & Bobot \\
\hline 1 & Daunya menguning & 6,25 \\
\hline 2 & Akar membusuk & 6,25 \\
\hline 3 & $\begin{array}{l}\text { Pangkal batang permukaanya ditumbuhi } \\
\text { meselium jamur berwarna putih }\end{array}$ & 6,25 \\
\hline 4 & $\begin{array}{l}\text { Terbentuk badan buah berwarna orange di } \\
\text { pangkal batang }\end{array}$ & 6,25 \\
\hline 5 & Daunya kusam menguning & 2,5 \\
\hline 6 & $\begin{array}{l}\text { Akar yang terserang ditumbuhi jamur berwarna } \\
\text { merah dengan ujung berwarna putih }\end{array}$ & 2,5 \\
\hline 7 & $\begin{array}{l}\text { Hifa jamur menempel kuat dan mengikat } \\
\text { butiran-butiran tanah }\end{array}$ & 2,5 \\
\hline 8 & $\begin{array}{l}\text { Badan buah jamur berwarna merah coklat } \\
\text { keras dan keriput }\end{array}$ & 2,5 \\
\hline 9 & $\begin{array}{l}\text { Permukaan bidang sadap berbercak cekung dan } \\
\text { berwarna putih }\end{array}$ & 5 \\
\hline 10 & Permukaan bidang sadap menjadi luka berkayu & 5 \\
\hline 11 & $\begin{array}{l}\text { Permukaan kulit pulihan dekat irisan sadap } \\
\text { bercak-bercak mengendap }\end{array}$ & 3,33 \\
\hline 12 & $\begin{array}{l}\text { Permukaan jalur sadap baru akan ditumbuhi } \\
\text { kapang seperti beledu ke abu-abuan }\end{array}$ & 3,33 \\
\hline 13 & Kulit pulihan tidak terbentuk sempurna & 3,33 \\
\hline 14 & $\begin{array}{l}\text { Tanaman yang disadap tidak mengeluarkan } \\
\text { lateks (getah) }\end{array}$ & 5 \\
\hline 15 & $\begin{array}{l}\text { Kulit tanaman tidak mengeluarkan getah } \\
\text { berwarna coklat }\end{array}$ & 5 \\
\hline 16 & $\begin{array}{l}\text { Luasan kulit yang menderita KAS tergantung } \\
\text { dari beratnya serangan KAS }\end{array}$ & 5 \\
\hline 17 & $\begin{array}{l}\text { Menggerogoti bibit yang baru saja ditanam } \\
\text { dilahan }\end{array}$ & 6,67 \\
\hline 18 & $\begin{array}{l}\text { Menggerek batang dari ujung daun sampai ke } \\
\text { akar }\end{array}$ & 6,67 \\
\hline 19 & Memakan akar pohon & 6,67 \\
\hline 20 & Menusuk pucuk batang dan daun muda & 3,33 \\
\hline 21 & Ranting lemah dan daun berguguran & 3,33 \\
\hline 22 & Terdapat jelaga hitam dipermukaan daun & 3,34 \\
\hline
\end{tabular}

2) Planning: Dalam tahap ini, pengumpulan kebutuhan dilakukan melalui 4 tahapan guna menunjang pengembangan sistem deteksi penyakit dan hama tanaman karet. Sub tahap tersebut antara lain, objek penelitian, observasi, wawancara, penyusunan kebutuhan sofware dan hardware.

3) Modeling: Dalam tahap ini terdapat 3 tahap proses yaitu rule base dari 7 kasus, sampel perhitungan menggunakan Algoritma Nearest Neighbor (KNN), dan merancang desain sistem menggunakan Use Case Diagram, Activity Diagram, dan Class Diagram yang bertujuan untuk mempermudah proses pembuatan sistem. Rule base yang dirancang dalam penelitian ini terdiri dari 7 rule tentang penyakit dan hama pada tanaman karet. Berikut penjelasan mengenai masing-masing rule base:

\section{Rule base kasus 1}

IF Daunya menguning

AND Akar membusuk

AND Pangkal batang permukaanya ditumbuhi meselium jamur berwarna putih

AND Terbentuk badan buah berwarna orange di pangkal batang 
THEN Penyakit Jamur Akar Putih

Rule base kasus 2

IF Daunya kusam menguning

AND Akar yang terserang ditumbuhi jamur berwarna merah dengan ujung berwarna putih

AND Hifa jamur menempel kuat dan mengikat butiranbutiran tanah

AND Badan buah jamur berwarna merah coklat keras dan keriput

THEN Penyakit Jamur Akar Merah

\section{Rule base kasus 3}

IF Permukaan bidang sadap berbercak cekung dan berwarna putih

AND Permukaan bidang sadap menjadi luka berkayu

THEN Penyakit Bidang Sadap Kanker Garis

\section{Rule base kasus 4}

IF Permukaan kulit pulihan dekat irisan sadap bercak-bercak mengendap

AND Permukaan jalur sadap baru akan ditumbuhi kapang seperti beledu ke abu-abuan

AND Kulit pulihan tidak terbentuk sempurna

THEN Penyakit Mouldy Rot

Rule base kasus 5

IF Tanaman disadap tidak mengeluarkan lateks (getah)

AND Kulit tanaman tidak mengeluarkan getah berwarna coklat

AND Luasan kulit yang menderita KAS tergantung dari beratnya serangan KAS

THEN Penyakit Brown Blast (Kering alur sadap)

\section{Rule base kasus 6}

IF Menggerogoti bibit yang baru saja ditanam dilahan

AND Menggerek batang dari ujung daun sampai ke akar

AND Memakan akar pohon

THEN Terserang Hama Rayap

\section{Rule base kasus 7}

IF Menusuk pucuk batang dan daun muda

AND Ranting lemah dan daun berguguran

AND Terdapat jelaga hitam dipermukaan daun

THEN Terserang Hama Kutu

Selain membangun rule base, dalam penelitian ini juga melakukan perhitungan sampel dengan menggunakan algoritma KNN dengan ketentuan sebagai berikut. Misalkan ada kasus baru:

a. Badan buah jamur berwarna merah coklat keras dan keriput.

b. Daunya kusam menguning.

c. Daunya menguning. d. Hifa jamur menempel kuat dan mengikat butiranbutiran tanah.

Perhitungan untuk menghitung apakah tanaman karet tersebut terkena penyakit Penyakit Jamur Akar Putih adalah sebagai berikut, similarity (Kasus 1 Penyakit Jamur Akar Putih), (Kasus baru):

$$
\text { Similarity }(\mathrm{T}, \mathrm{S})=\frac{\mathrm{S} 1 * \mathrm{~W} 1+\mathrm{S} 2 * \mathrm{~W} 2+\ldots \ldots+\mathrm{Sn} * \mathrm{Wn}}{\mathrm{W} 1+\mathrm{W} 2+\ldots \ldots+\mathrm{Wn}}
$$

$=\left[(6,25 * 0)+(2,5 * 0)+(6,25 * 0)+\left(2,5^{*} 0\right)+(2,5 * 0)+\right.$

$\left(6,25^{*} 10\right)+\left(2,5^{*} 0\right)+\left(3,33^{*} 0\right)+\left(5^{*} 0\right)+\left(5^{*} 0\right)+(6,67 * 0)$

$+(3,33 * 0)+(5 * 0)+(5 * 0)+(3,33 * 0)+(3,33 * 0)+(5 * 0)$

$+(6,25 * 0)+(3,33 * 0)+(3,34 * 0)+(6,67 * 0)+(6,67 * 0)] /$

$6,25+2,5+6,25+6,25+2,5+2,5+2,5+3,5+5+5+$

$6,67+3,33+5+5+5+3,33+3,33+6,25+3,33+3,34+$

$6,67+6,67$

$=62,5 / 100$

$=0,625$

Jadi nilai similarity dari kasus baru yang di inputkan dengan kasus lama Penyakit Jamur Akar Putih adalah 0,625. Perhitungan mencari nilai kedekatan antara kasus baru dengan kasus lama dilakukan hingga sampai 7 tahapan dari semua penyakit dan hama. Dari 7 kasus dicari nilai rata-rata yang mendekati antara kasus baru dengan kasus lama tersebut. Setelah proses mencari nilai kedekatan selesai kemudian metode Case based reasoning mengambil sebuah keputusan yaitu mencocokan gejala baru yang di inputkan dengan gejala kasus lama dari pengalaman Pakar. Setelah itu, untuk mengembangkan sistem pakar perlu dirancang dalam bentuk use case diagram agar memudahkan dalam pembuatan aplikasi. Tampilan use case diagram dapat dilihat pada gambar 3.

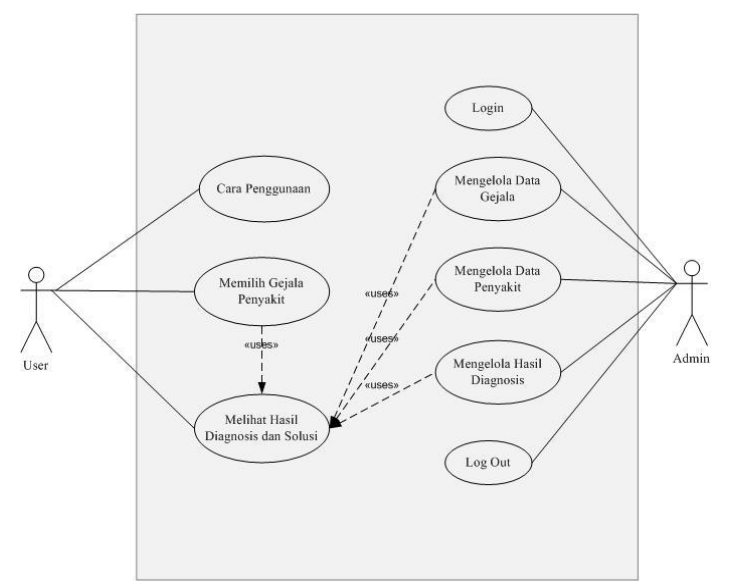

Gambar 3. Use case diagram sistem pakar diagnosa penyakit dan hama tanaman karet

4) Construction: Pada tahapan ini terdapat rancangan struktur database dan perancangan antarmuka untuk desain sistem dan database yang diterapkan ke sebuah sistem untuk diagnosa penyakit dan hama pada tanaman karet. 
5) Deployment: Pada proses pengujian ini, peneliti menggunakan Blackbox testing. Blackbox testing merupakan penjelasan sistem secara terstruktur setelah sistem tersebut selesai. Dengan memerhatikan kesalahankesalahan yang tidak sesuai dan diperlukan suatu perbaikan. Setelah sistem selesai sesuai dengan keinginan, maka sistem dapat diimplementasikan oleh user.

\section{IV.HASIL}

Pada tahapan ini, disajikan hasil implementasi sistem pakar untuk mendeteksi penyakit dan hama pada tanaman karet. Tampilan beranda dari sistem pakar dalam penelitian ini dapat dilihat pada gambar 4 .

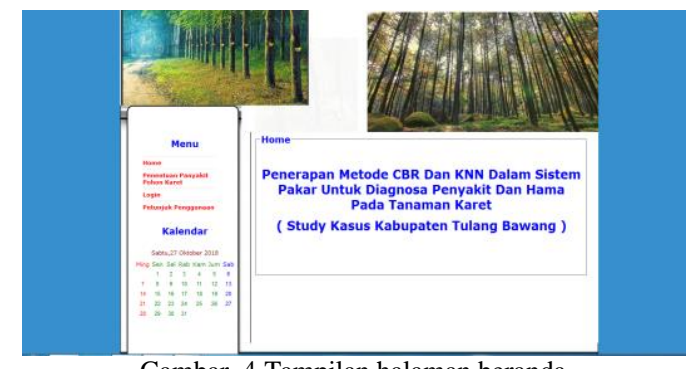

Gambar. 4 Tampilan halaman beranda

Proses identifikasi penyakit pada tanaman karet dapat dilakukan dengan memilih secara benar gejala-gejala yang dialami tanaman karet agar hasilnya sesuai dengan pakar. Tampilan halaman penentuan penyakit pada tanaman karet dapat dilihat pada gambar 5 .

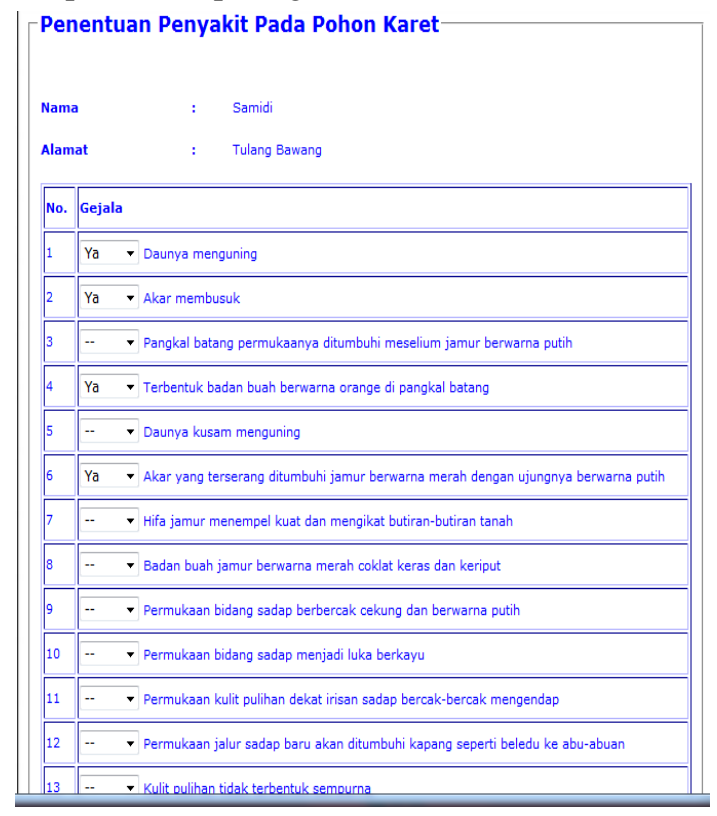

Gambar. 5 Tampilan halaman penentuan penyakit karet

Setelah sistem melakukan perhitungan berdasarkan kasus-kasus lama yang telah user inputkan sebelumnya maka sistem akan menentukan apa penyakit atau hama yang di alami tanaman karet sesuai dengan gejala atau rule yang sudah di berikan oleh pakar. Tampilan hasil diagnosa penyakit pada tanaman karet dapat dilihat pada gambar 6.

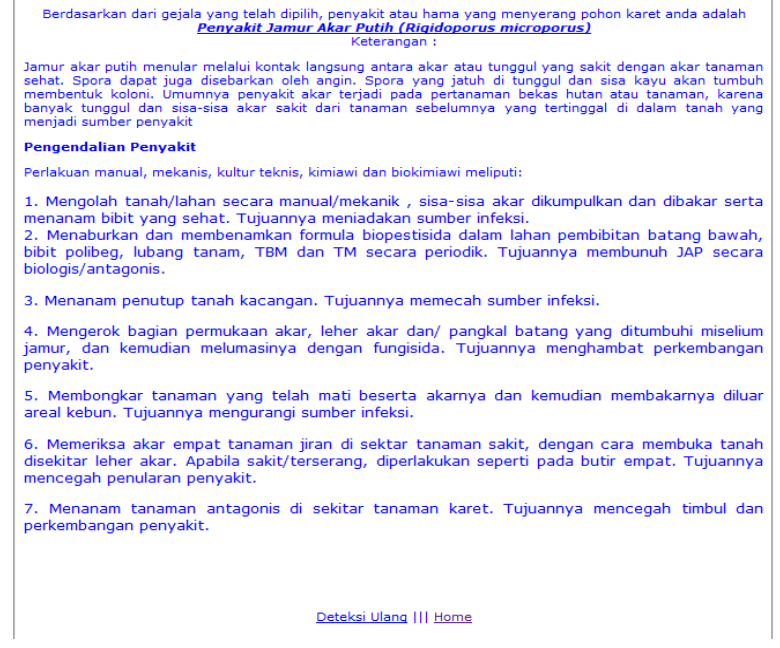

Gambar. 6 Hasil diagnosa penyakit tanaman karet

Setelah sistem berhasil dikembangkan, tahapan selanjutnya yaitu melakukan pengujian sistem. Pengujian sistem perlu dilakukan untuk menemukan kesalahan atau kelemahan yang mungkin masih terjadi, sehingga perlu dilakukan perbaikan sistem. Dalam penelitian ini, pengujian perangkat lunak dilakukan dengan metode Black Box Testing, yang dapat dilihat pada tabel 2.

TABEL II

PENGUJIAN TAMPILAN DAFTAR USER

\begin{tabular}{|l|l|l|l|}
\hline \multicolumn{1}{|c|}{ Skenario } & Hasil & \multicolumn{1}{|c|}{ Pengamatan } & Kesimpulan \\
\hline $\begin{array}{l}\text { Input nama } \\
\text { dan alamat }\end{array}$ & $\begin{array}{l}\text { Hasil } \\
\text { inputan }\end{array}$ & $\begin{array}{l}\text { Masuk ke } \\
\text { pemilihan gejala }\end{array}$ & $\begin{array}{l}\text { Diterima[`] } \\
\text { Ditolak [ ] }\end{array}$ \\
\hline & Muncul & Tidak dapat & \\
Field nama & pesan & $\begin{array}{l}\text { masuk ke dalam } \\
\text { dikosongkan }\end{array}$ & Diterima[ $\checkmark$ ] \\
& Belum Di & $\begin{array}{l}\text { menu pemilihan } \\
\text { data gejala }\end{array}$ & Ditolak [ ] \\
& isi" & & \\
\hline
\end{tabular}

Selain melakukan pengujian terhadap tampilan sistem dengan menggunakan metode black box, dalam penelitian ini juga dilakukan pengujian dengan membandingkan hasil perhitungan secara manual dan hasil perhitungan dengan menggunakan sistem. Sebagai contoh, uji coba perhitungan manual untuk perhitungan nilai Similarity dengan algoritma KNN. Untuk melakukan perhitungan, misalkan diketahui kasus baru memiliki gejala sebagai berikut:

a. Daunya menguning

b. Akar membusuk

c. Pangkal batang permukaanya ditumbuhi meselium jamur berwarna putih

d. Terbentuk badan buah berwarna orange di pangkal batang

Berdasarkan hasil perhitungan menggunakan sistem diperoleh bahwa dengan memilih gejala penyakit tanaman karet sesuai dengan kasus di atas, makapenyakit atau hama yang menyerang tanaman karet anda adalah Penyakit Jamur. Sedangkan jika dilakukan perhitungan secara manual, nilai similiarity dari kasus tersebut adalah sebagai berikut: 
Diketahui nilai bobot dari masing-masing gejala adalah sebagai berikut:

a. Daunya menguning $=6,25$

b. Akar membusuk $=6,25$

c. Pangkal batang permukaanya ditumbuhi meselium jamur berwarna putih $=6,25$

d. Terbentuk badan buah berwarna orange di pangkal batang $=6,25$

Similarity $=\frac{(6,25 \times 1)+(6,25 \times 1)+(6,25 \times 1)+(6,25 \times 1)}{6,25+6,25+6,25+, 6,25}=1$

Gejala yang telah dipilih yang disebut dengan kasus baru dengan gejala yang dimiliki oleh salah satu data tanaman karet di dalam knowledge base (kasus lama) sehingga perhitungannya adalah sebagai berikut :

Hitung persentase: 1 x 100\% $=100 \%$

Setelah itu akan dilakukan pengujian dengan melakukan uji coba pada sejumlah data masukan. Pengujian yang dilakukan diantaranya adalah pengujian satu gejala satu jenis penyakit, satu gejala beberapa jenis penyakit, beberapa gejala satu jenis penyakit dan beberapa gejala dengan beberapa penyakit. Selain itu, dilakukan juga pengujian keakuratan atau kesesuaian dari data testing yang diperoleh dari pakar dengan hasil keluaran sistem [4]. Dalam pengujian ini dilakukan percobaan sebanyak 20 kali dengan masukan yang sesuai dengan data testing. Dari percobaan tersebut diperoleh informasi sebagai berikut:

a. Jumlah data masukan $=20$

b. Jumlah hasil diagnosa yang sesuai dengan pakar $=16$

c. Jumlah hasil diagnosa salah $=4$

Akurasi $=$ jumlah data diagnosa sesuai $x 100 \%$ Jumlah data masukan

Sehingga didapat perhitungan sebagai berikut:

$$
\begin{aligned}
\text { Akurasi } & =\frac{16}{20} \times 100 \% \\
& =80 \%
\end{aligned}
$$

Dari hasil pengujian yang dilakukan, maka tingkat akurasi kesesuaian dari data testing yang didapatkan oleh pakar dengan hasil keluaran sistem adalah sebesar $80 \%$.

\section{KESIMPULAN}

Berdasarkan dari penelitian yang telah dilakukan, dapat disimpulkan sebagai berikut:

1. Aplikasi yang dibuat dapat menentukan kerusakan pada tanaman karet yang di sebabkan oleh penyakit dan hama dengan menggunakan metode CBR dan KNN. Aplikasi ini di peruntukan untuk para petani karet khususnya yang ada di wilayah Tulang Bawang agar masyarakat ataupun petani setempat mengetahui apakah tanaman karet yang mereka tanam terserang penyakit dan hama atau tidak. Selain itu aplikasi juga dapat memberikan saran penanganan pertama serta edukasi bagaimana cara menanggulanginya.

2. Dari hasil pengujian yang dilakukan, tingkat akurasi kesesuaian dari data testing yang didapatkan oleh pakar dengan hasil keluaran sistem adalah sebesar $80 \%$.

Saran penelitian berikutnya:

1. Diperlukan adanya perbaikan bobot dari setiap gejala yang digunakan dalam pendeteksian penyakit tanaman karet.

2. Pengembangan sistem pakar berbasis mobile.

\section{REFERENSI}

[1] Budiman, Budi Daya Karet Unggul, Pustaka Baru, Yogyakarta, 2012.

[2] Z. Zulfariana \& Ernastuti, Aplikasi Sistem Informasi Geografis yang Memetakan Empat Bengkel Motor Resmi di Kota Depok Berbasis Platform Android, Universitas Gunadarma, 2013.

[3] Daniel \& G. Virginia, Implementasi Sistem Pakar untuk Mendiagnosis Penyakit dengan Gejala Deman Menggunakan Metode Certainty Factor, Jurnal Informatika, Volume 6 Nomor 1, 2010.

[4] A. Sucipto, Y. Fernando, R. I. Borman \& N. Mahmuda, Penerapan Metode Certainty Factor Pada Diagnosa Penyakit Saraf Tulang Belakang, Jurnal Ilmiah FIFO, Volume X/No. 2/November/2018.

[5] H. Sulistiani \& K. Mulidi, Penerapan Metode Certainty Factor Dalam Mendeteksi Penyakit Tanaman Karet, Jurnal Pendidikan dan Teknologi Kejuruan, 2018.

[6] S.R. Nasution, N.A. Hasibuan, \& P. Ramadhani, Sistem Pakar Diagnosa Anoreksia Nervosa Menerapkan Metode Case Based Reasoning, Konferensi Nasional Teknologi Informasi dan Komputer, Vol. 1 Nomor 1, 2017.

[7] Minarni \& I. Warman, Sistem Pakar Identifikasi Penyakit Tanaman Padi Menggunakan Case-Based Reasoning, Seminar Nasional Aplikasi Teknologi Informasi (SNATi), 2017.

[8] F. N. Salisah, L. Lidya, \& S. Defit, , Sistem Pakar Penentuan Bakat Anak dengan Menggunakan Metode Forward Chaining, urnal Rekayasa dan Manajemen Sistem Informasi, Vol. 1, No. 1, 2015.

[9] R. R. Fanny, N.A. Hasibuan, \& E. Buulolo, Perancangan Sistem Pakar Diagnosa Penyakit Asidosis Tubulus Renalis Menggunakan Metode Certainty Factor dengan Penelusuran Forward Chaining, Media Informatika BudiDarma, Vol. 1 No. 1, 2017.

[10] A. S. Honggowibowo, Sistem Pakar Diagnosa Penyakit Tanaman Padi Berbasis Web dengan Forward dan Backward Chaining, Telkomnika, Vol. 7 No. 3, 2009.

[11] A. Sulistyohati \& T. Hidayat, Aplikasi Sistem Pakar Diagnosa Penyakit Ginjal dengan Metode Dempster Shafer, Seminar Nasional Teknologi Informasi (SNATi), 2008.

[12] R. Maulana, J. Fitriyadi dan R. Fitriani, Sistem Pakar Diagnosis Penyakit Tanaman Karet Dengan Metode Dempster-Shafer. STMIK Banjarbaru. 2013.

[13] S. Hartati dan S. Iswanti, Sistem Pakar dan Pengembangannya. Yogyakarta: Graha Ilmu. 2008.

[14] S. Muzid, Teknologi penalaran berbasis kasus (case based reasoning) untuk Diagnosa Penyakit Kehamilan. Yogyakarta, Universitas Islam Indonesia. 2008.

[15] A. Aamodt \& E. Plaza, Case Based Reasoning: Foundation issues, methodological variation and System approach.1994.

[16] Kusrini. Sistem Pakar, Teori dan Aplikasi. Yogyakarta: Andi. 2006.

[17] Y. I. Nurhakim, dan A. Hani, Perkebunan Karet Skala Kecil Cepat Panen Secara Otodidak. Intra Pustaka, Depok. 2014. 